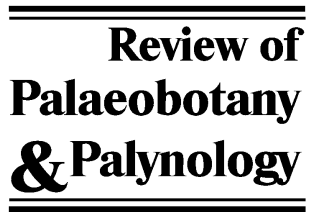

www.elsevier.com/locate/revpalbo

\title{
Advantages and disadvantages of phytolith analysis for the reconstruction of Mediterranean vegetation: an assessment based on modern phytolith, pollen and botanical data (Luberon, France)
}

\author{
Laurent Bremond $^{\mathrm{a}, *}$, Anne Alexandre ${ }^{\mathrm{a}}$, Errol Véla ${ }^{\mathrm{b}}$, Joël Guiot ${ }^{\mathrm{a}}$ \\ ${ }^{a}$ CEREGE, Méditerranéen de l'Arbois, B.P. 80, Aix-en-Provence Cedex 04 F-13545, France \\ ${ }^{\mathrm{b}}$ IMEP, Europôle Méditerranéen de l'Arbois, B.P. 80, Aix-en-Provence Cedex 04 F13545, France
}

Received 12 February 2003; accepted 6 February 2004

\begin{abstract}
We present here the results of a first study comparing modern soil phytolith assemblages with pollen and botanical data at a North Mediterranean site. This work has shown the following limitations and advantages of phytolith analysis for the reconstruction of Mediterranean vegetation:

(1) Phytoliths are produced in sufficient quantities for analysis and are well preserved in limestone environments, widespread in the Mediterranean area. (2) Young stands of Quercus ilex and Quercus coccifera, widely distributed in the Mediterranean area do not produce characteristic phytolith types in sufficient quantities to allow the calculation of a reliable index of tree cover density. (3) Pine forests, dominated by Pinus halepensis and Pinus sylvestris, are not recorded in the studied phytolith assemblages. (4) Grassland and shrubland assemblages can be distinguished through their associated phytolith assemblages, in particular by the proportion of crenate phytoliths produced in the short cells of the grass epidermis. (5) The different vegetation groups on the massif cannot be distinguished by pollen analysis. Further studies, comparing modern phytolith assemblages and quantitative vegetation data, should be carried out on forest plots that have been established for several centuries to further assess the role of phytolith analysis in vegetation reconstructions in the Mediterranean region.
\end{abstract}

(C) 2004 Elsevier B.V. All rights reserved.

Keywords: phytolith; modern; Mediterranean; paleovegetation; pollen

\section{Introduction}

Previous reconstructions of the past vegetation in the continental Mediterranean zone have been mainly based on pollen (Prentice et al., 1996; Cheddadi et al., 1997; Peyron et al., 1998; Fauquette et al., 1999;

\footnotetext{
* Corresponding author.

E-mail address: Bremond@cerege.fr (L. Bremond).
}

Guiot et al., 1999; Jalut et al., 2000; Cheddadi et al., 2001), charcoal (Thinon, 1979, 1992; Thiébault, 1997; Heinz and Thiébault, 1998) and plant macrofossil (Vernet, 1997; Digerfeldt et al., 1997) data. However, non-oxidizing areas such as peat bogs or lacustrine sediments in which pollen are preserved are scarce in the Mediterranean zone. Continental records from coastal (Rose et al., 1999; Jalut et al., 2000) and marine (Combourieu-Nebout et al., 1998) sediments 
record a signal from a larger spatial scale as they receive an influx of pollen from various sources. Further, none of those proxies are able to trace grassland dynamics and forest-grassland shifts over time with any accuracy.

Phytoliths are amorphous silica particles that precipitate in and/or between the cells of living plant tissues. As phytoliths are well preserved in oxidizing environments such as soils or buried soils, they may therefore help to compensate for the current lack of continental paleovegetation reconstructions in the Mediterranean area. Previous phytolith investigations have mostly concentrated on inter-tropical and tem- perate paleoenvironmental records. There are only a few existing studies from the Mediterranean region (Albert et al., 1999, 2000; Delhon et al., 2003) and even fewer studies of the calibration of modern soil surface phytolith assemblages with defined vegetations (Delhon et al., 2003). We present here an assessment of the advantages and limitations of phytolith analysis for the reconstruction of the past vegetation in the North Mediterranean area, based on the study of modern soil phytolith assemblages. Thirty-one modern soil phytolith assemblages and ten modern soil pollen assemblages are compared with mesological and exhaustive botanical surveys (Véla,

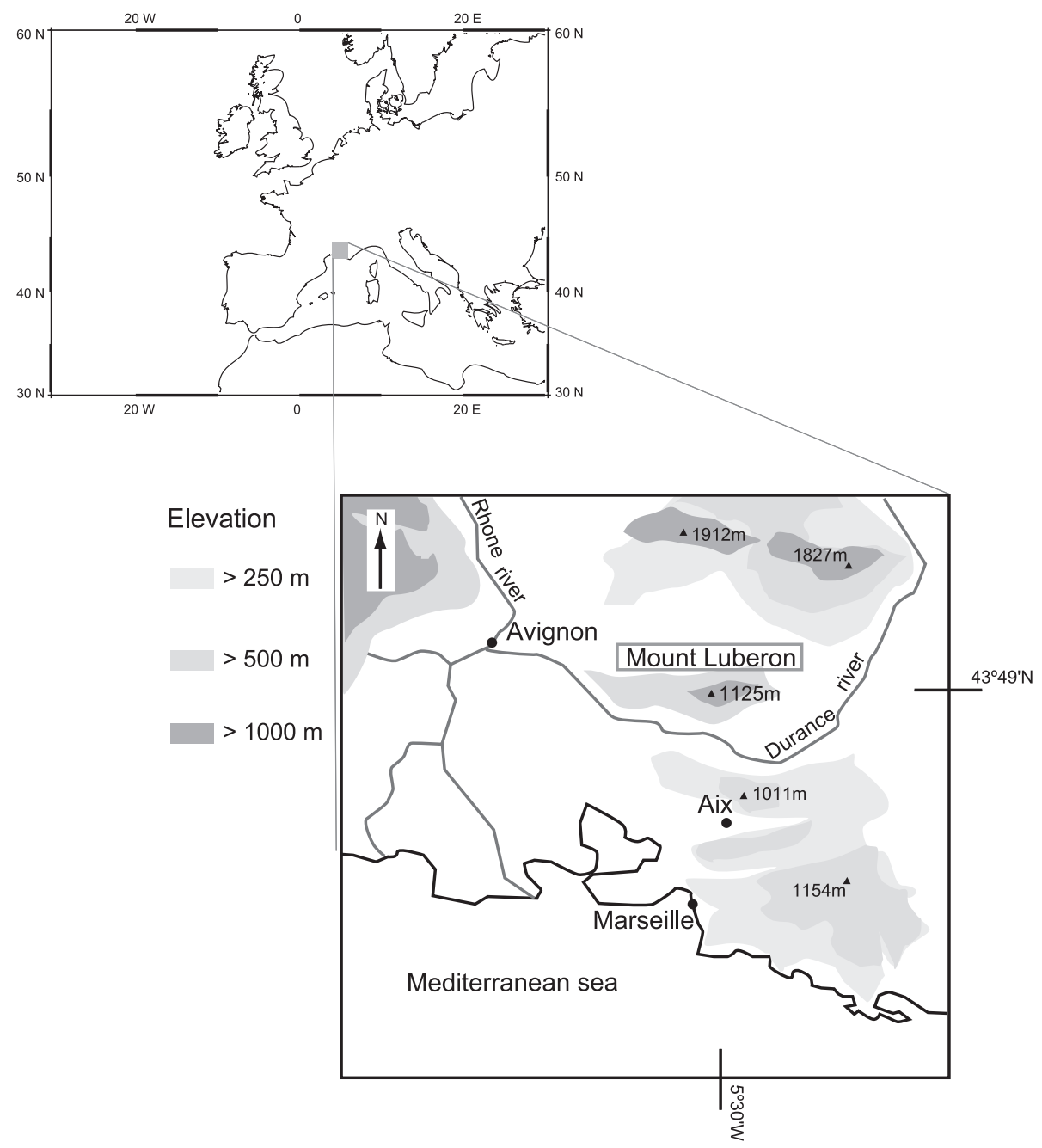

Fig. 1. Location of the sampled site; Mont Luberon, southeast of France. 
2002) in order to answer the following methodological questions:

(1) Soils developed from limestone parent-rocks, such as leptosols (F.A.O., 1998), are widespread in the Mediterranean area. These soils do not contain a large amount of silica available for plant uptake. Does the vegetation occurring in these regions produce phytoliths, and do the soils contain sufficient phytoliths for reliable counting and analysis?

(2) In contrast to pollen data, phytolith morphological types help to discriminate grass subfamilies (Twiss, 1987, 1992; Fredlund and Tieszen, 1994, 1997). To what extent is this information important for the reconstruction of northern Mediterranean vegetation?

(3) In inter-tropical areas, the tree cover density is mirrored through the phytolith index $\mathrm{d} / \mathrm{p}$ (the ratio of dicotyledon phytolith type to the sum of Poaceae phytoliths) (Alexandre et al., 1997). Does the same phytolith index reflect the tree cover density in the North Mediterranean zone indicated, as suggested by Delhon et al. (2003)?

(4) Pine species are currently widespread in the Mediterranean area. Several phytolith studies have suggested that pine populations produce characteristic phytolith types (Klein and Geis, 1977; Sangster et al., 1997; Kerns, 2001; Kerns et al., 2001; Blinnikov et al., 2002; Delhon et al., 2003). Are the pine phytolith proportions found in phytolith assemblages indicative of the above pine cover density?

(5) The Mediterranean vegetation physiognomy may be highly heterogeneous over short distances (Di Castri et al., 1981; Blondel and Aronson, 1999). What spatial and time scales are recorded in soil phytolith assemblages?

Table 1

Definition and history of the current vegetation types covering the sampled plots

\begin{tabular}{|c|c|c|c|}
\hline Vegetation types & Plot name & Dynamics of the vegetation & Estimated ages \\
\hline Grassland/Cedrus atlantica & CPL04 & \multirow[t]{13}{*}{ grassland to non-native Cedrus forest } & younger than 50 years \\
\hline Grassland & CPL06 & & stable $(>100$ years $)$ \\
\hline Grassland & CPL11 & & stable (>100 years) \\
\hline Grassland & GLC08 & & stable $(>100$ years $)$ \\
\hline Grassland & GLC15 & & stable ( $>100$ years $)$ \\
\hline Grassland & GLC20 & & stable ( $>100$ years $)$ \\
\hline Grassland & GLE15 & & stable ( $>100$ years) \\
\hline Grassland & GLE21 & & stable ( $>100$ years $)$ \\
\hline Grassland & GLW03 & & stable ( $>100$ years) \\
\hline Grassland & GLW04 & & stable ( $>100$ years $)$ \\
\hline Grassland & HP02 & & stable ( $>100$ years $)$ \\
\hline Grassland & HP05 & & stable ( $>100$ years) \\
\hline Grassland with oak shrub & TR12 & & stable ( $>100$ years $)$ \\
\hline Grassland/oak grove & GLE04 & \multirow[t]{5}{*}{ grassland to shrubland } & younger than 50 years \\
\hline Oak and beech forest & GLC05 & & stable $(>100$ years $)$ \\
\hline Oak grove & GLC13 & & stable ( $>100$ years $)$ \\
\hline Oak grove & HP04 & & stable ( $>100$ years $)$ \\
\hline Shrubland & CM17 & & stable $(>100$ years $)$ \\
\hline Shrubland & CPL01 & grassland to shrubland & younger than 100 years \\
\hline Shrubland & CPL12 & grassland to grassed glade & younger than 50 years \\
\hline Shrubland & GLW07 & grassland to Buxus sempervirens shrubland & younger than 50 years \\
\hline Shrubland & HP08 & grassland to shrubland & younger than 50 years \\
\hline Shrubland & TR19 & oak grove to shrubland & younger than 50 years \\
\hline Shrubland & TR21 & grassland to shrubland & younger than 50 years \\
\hline Shrubland/grassland & GLC14 & & stable $(>100$ years $)$ \\
\hline Shrubland/grassland & TR14 & \multirow[t]{3}{*}{ grassland to shrubland } & younger than 100 years \\
\hline Pinewood with Poaceae & CM05 & & younger than 100 years \\
\hline Pinewood with Poaceae & GLC07 & & younger than 100 years \\
\hline Pinewood with Poaceae & TR06 & \multirow{3}{*}{$\begin{array}{l}\text { shrubland to pinewood } \\
\text { grassland to pinewood }\end{array}$} & younger than 50 years \\
\hline Pinewood with Poaceae & GLC19 & & younger than 50 years \\
\hline Pinewood with Poaceae & CM06 & & younger than 100 years \\
\hline
\end{tabular}




\section{Location of study sites}

The Luberon mountain range $\left(43^{\circ} 49 \mathrm{~N}, 5^{\circ} 30^{\prime} \mathrm{W}\right)$ is situated in the southeastern Mediterranean part of France, to the north of Marseille (Fig. 1). The range is oriented east-west and lies between 300 and $1124 \mathrm{~m}$ above sea level (a.s.1.). The substratum is made of Cretaceous and Oligocene limestone containing less than $8 \%$ of $\mathrm{SiO}_{2}$. The sampled soils are leptosols (F.A.O., 1998), a few centimeters thick, with a thin humic layer.

The massif is located in the Mediterranean subhumid climate zone defined by cold winters. Annual rainfall is $700 \mathrm{~mm}$. The vegetation of the western Luberon is organized in three zones linked to topoclimatic conditions (Tatoni et al., 1998; Véla et al., 1998): (1) mixed evergreen and summergreen oak grove found on the northern slopes; (2) the southern slopes are covered by grasslands and shrublands with patches of pinewood (Pinus halepensis); (3) the summit is covered with grasslands with small bushes. These high-altitude grasslands have been influenced by grazing over a number of centuries (Véla et al., 1998).

The site was chosen because exhaustive botanical surveys have been done by one of the co-authors (Véla, 2002). As elsewhere in the Mediterranean region, human impact through fires, grazing and cultivation has been important in the Luberon range. Vegetation changes in the last century have been considered for every plot (Table 1). Where grazing has ceased in the last 50 years, the grasslands have been progressively replaced by shrublands.

\section{Materials and methods}

\subsection{Sampling}

In order to have a relevant representation of the different vegetation types found on the massif, sample sites were chosen from 155 plots according to their botanical content (Véla, 2002), representative of pinewood, oak grove, shrubland or grassland. The first centimeter of humic horizon of 31 plots of $20 \times 20 \mathrm{~m}^{2}$ were sampled (Table 1). Phytolith and pollen samples of $50 \mathrm{~g}$ consisted of five sub-samples collected at the center of the plot and at the four middle points of the diagonals.
As the sampled soils are all leptosols, impact of soil environment is not taken into account when discussing selective preservation of phytolith assemblages from one plot to another.

\subsection{Vegetation survey}

Botanical surveys were carried out following Godron et al. (1983). More than 300 species were classified. Every individual of the same species was counted and then classified into one of six classes based on the abundance of that species (calculated as a proportion of the sum of all counted individuals): scarce (class 0.5 ), less than $10 \%$ (class 1 ), from $10 \%$ to $25 \%$ (class 2 ), from $25 \%$ to $50 \%$ (class 3 ), from $50 \%$ to $75 \%$ (class 4 ) and higher than $75 \%$ (class $5)$. The data are presented here as fixed percentages equal to the middle value of the class and adjusted to $100 \%$. This transformation from the class counting method into percentage data, necessary for statistical treatments, may induce an error of up to $30 \%$.

The dominant Poaceae species found are Bromus erectus, Festuca ovina group (Festuca marginata and Festuca gracilior), Brachypodium retusum, Stipa pennata, Poa bulbosa and Koeleria valesiana. These species belong to the Pooideae subfamily. The dominant ligneous dicotyledons are oaks (Quercus coccifera, Quercus pubescens and Quercus ilex) and, to a lesser extent, thyme (Thymus vulgaris), a little shrub. Pinaceae species are dominated by Pinus halepensis and Pinus sylvestris (Pinus nigra planted on GLC07 plot). The proportion of dominant ligneous dicotyledon, Poaceae and Pinaceae species per plot are shown in Fig. 2, with the plots grouped into four vegetation groups: grassland, shrubland, oak grove, and pinewood.

The change in the vegetation for each plot (Table 1) has been estimated by considering information on past pastoral habits, the estimated age of dominant trees, the vegetation structure and the species composition of communities (pioneer species) (Véla, 2002).

\subsection{Phytolith extraction and counting}

Phytoliths were extracted from $20 \mathrm{~g}$ of dry soil, following dissolution of carbonates, using $\mathrm{HCl}(3 \%)$, 


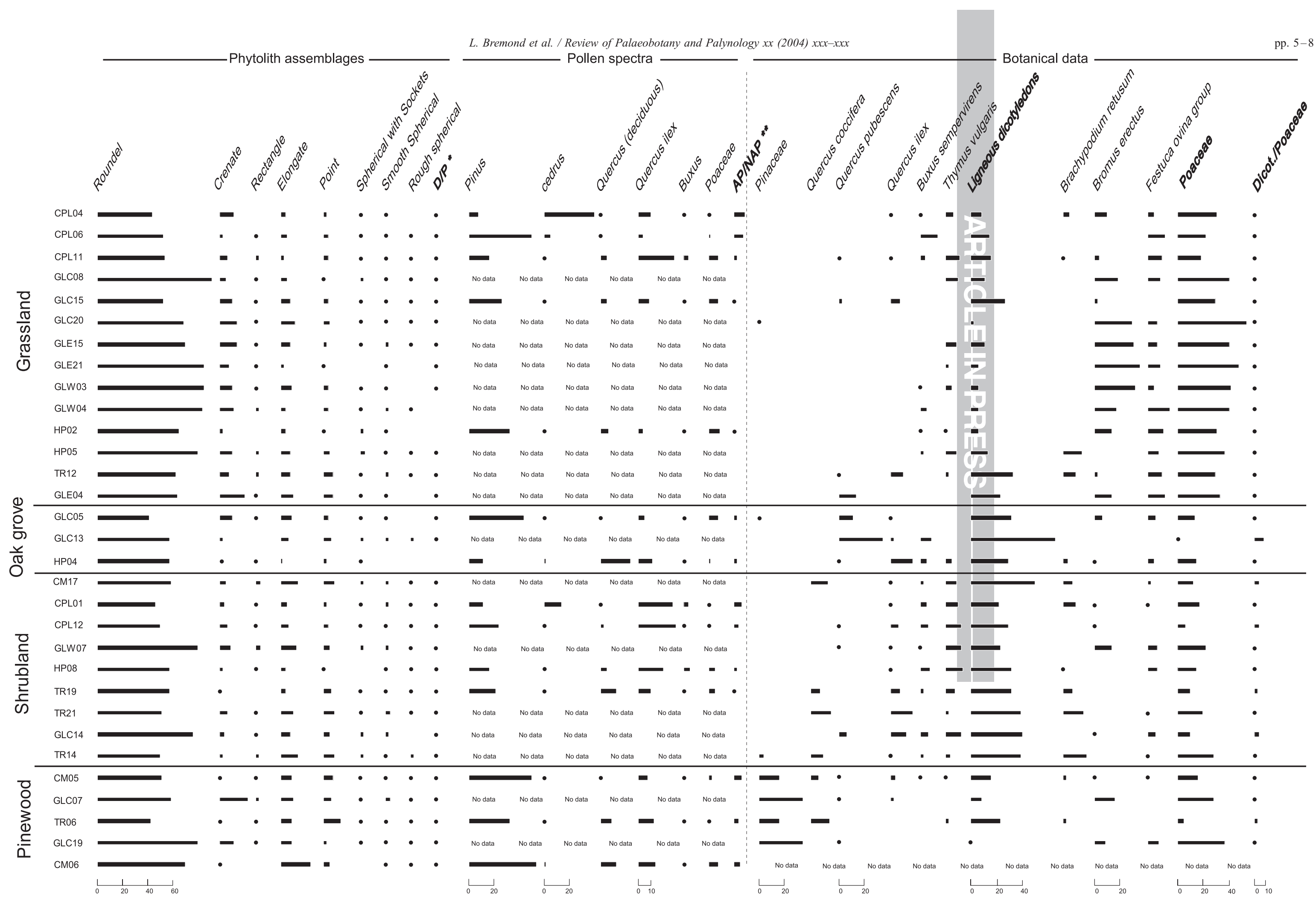

Fig. 2. Abundances of phytolith types (percentage of the characteristic phytolith sum), pollen (percentage of the counted pollen sum) and botanical species (percentage estimated after botanic statements following Godron et al. (1983)) for the studied plots. Abundance lower than $1 \%$ are figured by a dot. ${ }^{*} \mathrm{D} / \mathrm{P}=$ ligneous dicotyledon phytoliths (smooth and rough spherical types)/Poaceae phytoliths (roundel, crenate and rectangle types). ${ }^{* *} \mathrm{AP} / \mathrm{NAP}=$ arboreal pollens/non-arboreal pollens. 


\section{ARTICLE IN PRESS}

L. Bremond et al. / Review of Palaeobotany and Palynology xx (2004) xxx-xxx
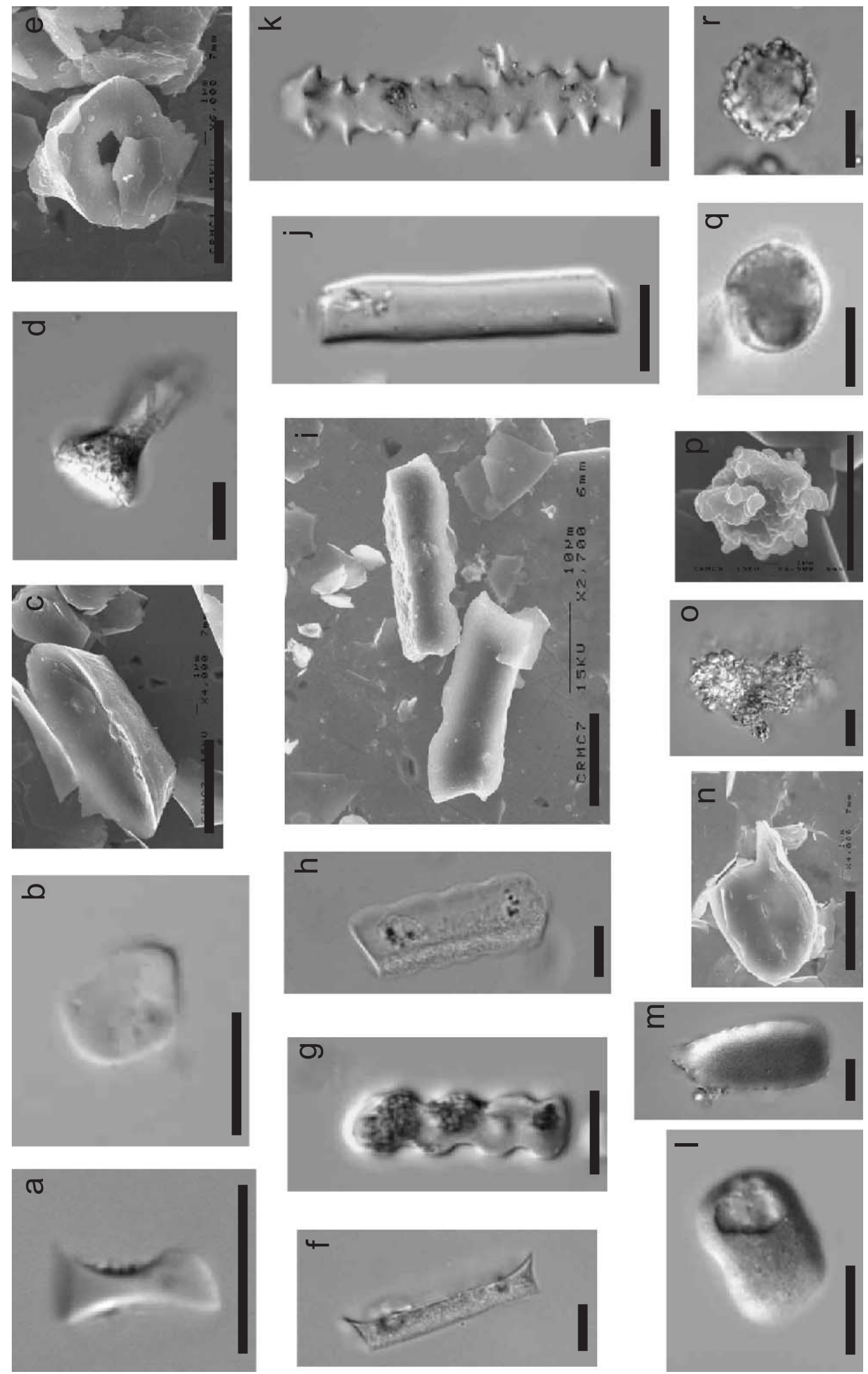
and oxidation of organic matter, using $30 \%$ hydrogen peroxide heated at $90{ }^{\circ} \mathrm{C}$ until reaction subsides. The samples were passed through a $60 \mu \mathrm{m}$ sieve and clays were removed according to the Stock law. Densimetric separation of phytoliths was carried out using zinc bromide heavy liquid $(d=2.3)$ (Kelly, 1990). The recovered fraction, including opal phytoliths and diatoms was weighed and mounted on microscope slides using glycerine for observation of the 3D shape, and Canada Basalm for counting. Microscopic observations were performed at $600 \times$ magnification. More than 200 characteristic phytoliths were counted from each sample. Only phytoliths with a diameter greater than $5 \mu \mathrm{m}$ and which could be taxonomically identified were counted. These were then classified using the classification of Twiss (1992) and Twiss et al. (1969), improved and completed by the phytolith shape descriptions of Fredlund and Tieszen (1994), Kondo et al. (1994), Alexandre et al. (1997) and Barboni et al. (1999). Identified phytolith types are illustrated in Fig. 3. Roundel, crenate and rectangle types are mainly produced in short cells of epidermis of the Pooideae grass subfamily (Twiss et al., 1969; Mulholland, 1989; Twiss, 1992), gathering $\mathrm{C}_{3}$-grasses abundant in temperate and North Mediterranean areas. The elongate type (smooth and sinuous are merged in the same group) are phytoliths from long-cells of all grass epidermis. The point-shaped type originate from micro-hair or prickles of all grass epidermis (Palmer et al., 1985; Kaplan et al., 1992).

Non-Poaceae taxa also produce characteristic phytolith types. The spherical rough phytolith type is produced by the wood of trees and shrubs (ligneous dicotyledon) in tropical areas (Scurfield et al., 1974; Kondo et al., 1994; Alexandre et al., 1997; Barboni et al., 1999). The "medium to large multifaceted polyhedrals" phytolith type produced by oaks (Kondo et al., 1994) have not been observed in the assemblages.

The smooth spherical type appears to have several origins. According to Kondo et al. (1994), this type is produced in the epidermis of leaves and in the ray or parenchyma cells of dicot twigs and wood. They have been recovered in small proportions from several tropical herbaceous monocots and in greater quantities from a small number of tropical arboreal dicot leaves and seeds (Piperno, 1988). Recent investigation of tropical grasses show that the smooth spherical type is also produced in significant amounts by grass roots (Alexandre et al., 2000).

The spherical-with-sockets type was also counted. This type has been described by Delhon et al. (2003) and has also been named the spiked type by Blinnikov et al. (2002) and the spiny body by Kerns (2001). These authors suggest that this type is produced by Pinaceae species.

Identification was possible for more than $60 \%$ of the counted phytoliths. Phytolith assemblages are presented in Fig. 2 as a percentage of the sum of classified phytoliths. A 5\% counting error was estimated by counting the phytoliths on a slide two times.

\subsection{Pollen counting and identification}

Pollen counting was carried out following the standard method of Reille (1990). At least 550 pollen grains were identified and counted at $\times 250$ and $\times 1000$ magnifications. Pollen conservation was high in all samples. Whilst a total of 88 taxa were identified, only those taxa present in significant quantities are shown in Fig. 2.

\section{Results}

\subsection{Phytoliths}

A sufficient amount of phytoliths was found in all soil samples (about $0.03 \%$ of the dry weight). Grass phytoliths, which include five types, made up between $86 \%$ and $99 \%$ of the classified types for all assemb-

Fig. 3. Photographs of representatives of the eight classes of phytolith types counted in this study (see text for explanation); Scale bar $=10 \mu \mathrm{m}$ : (a) microphotograph of a roundel type (Mulholland, 1989), side view; (b) microphotograph of a roundel type, top view; (c) SEM photograph of this roundel type, top view; (d) microphotograph of a second roundel type, side view; (e) SEM photograph of this roundel type, top view; (f) microphotograph of crenate type (Fredlund and Tieszen, 1994), side view; (g) microphotograph of crenate type, top view; (h) microphotograph of crenate type, under view; (i) SEM photograph of crenate type; (j, k) microphotograph of elongate type (Twiss et al., 1969); (l) microphotograph of rectangle type (Twiss et al., 1969); (m) microphotograph of point type (Twiss et al., 1969); (n) SEM photograph of point type; (o) microphotograph of spherical with sockets type; (p) SEM photograph of spherical with sockets type; (q) microphotograph of smooth spherical type; (r) microphotograph of rough spherical type. 


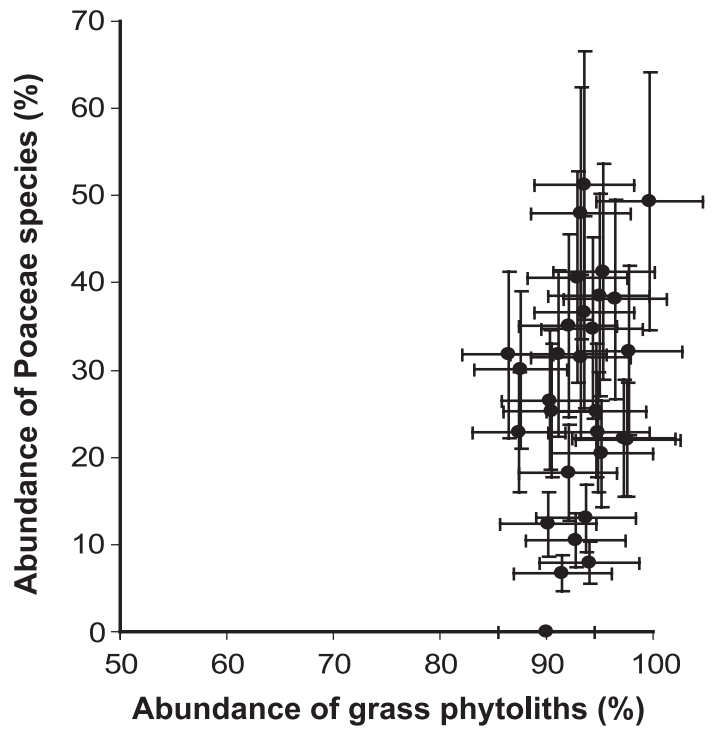

Fig. 4. Abundance of grass phytoliths versus abundance of Poaceae species recorded by botanical statement.

lages (Fig. 2). The roundel type is largely dominant in the assemblages, ranging from $53 \%$ to $89 \%$ and is homogeneously distributed between assemblages from the four vegetation groups. The crenate type accounts for $0-20 \%$ with high abundances occurring most frequently in the grassland group assemblages. The rectangle type accounts for $0-5 \%$ and does not show any pattern specific to the vegetation groups. These three phytolith types are characteristic of the Pooideae grass subfamily, which is the only grass subfamily represented on the plots. Elongate and point type phytoliths, which originate in the long-cells and micro-hairs of grass epidermis were present in quantities ranging between $3-22 \%$ and $1-18 \%$, respectively, with the highest abundance of the point-shaped phytoliths occurring in the non-grassland assemblages. The sum of all grass phytolith abundance has been plotted against the sum of Poaceae species recorded by botanical survey (Fig. 4). No obvious relation can be seen from this figure. After running numerous correlation analysis between the majority of the phytolith types and the botanical data (species or group of species), the best relationship found is between the crenate phytolith type abundance and the sum of Poaceae species (Fig. 5). As shown in Fig. 2, the shrubland plots with fewer Poaceae species $(8-32 \%$ of all botanical species) produce phytolith assemblages with lower proportions of the crenate type (less than $8 \%$ of the characteristic phytoliths). In

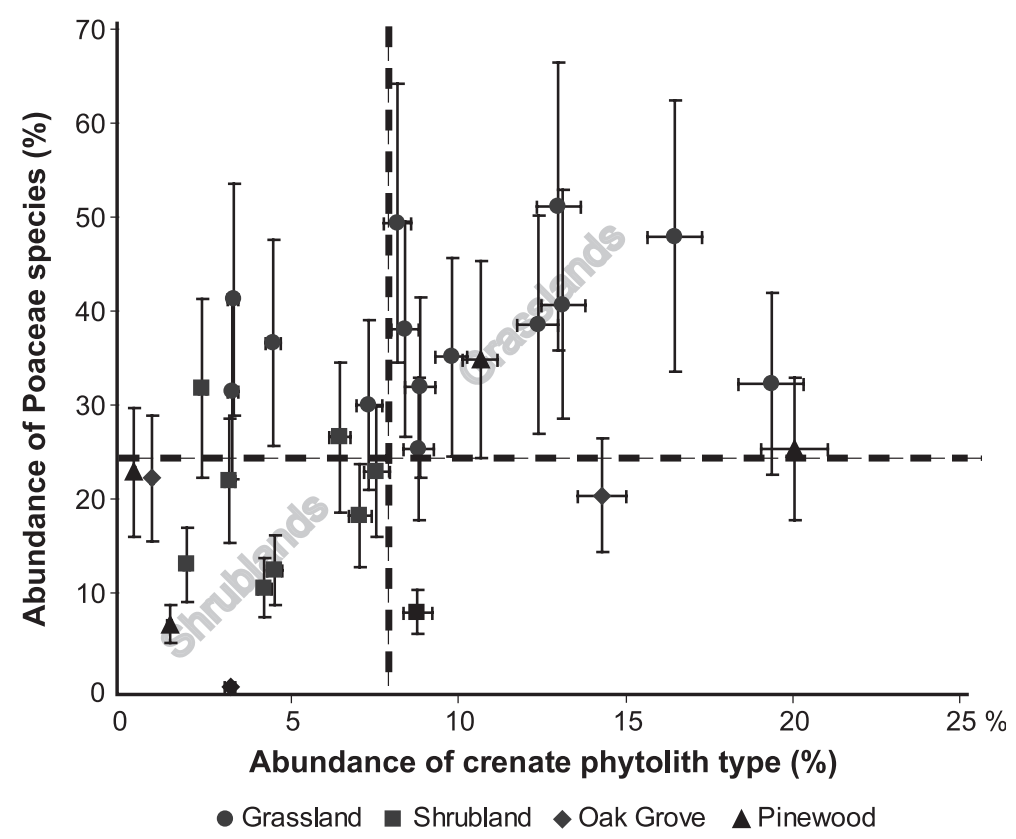

Fig. 5. Sum of the crenate phytolith type plotted versus the sum of Poaceae species recorded by botanical statement. 
comparison, most of the grassland plots produce phytolith assemblages with high proportion of the crenate type; although 4 of the 14 plots studied have a low abundance of this type.

The abundance of Poaceae species found in oak grove and pinewood plots varies widely $(7-35 \%)$, their phytolith assemblages also show a wide range of crenate type abundances $(0.3-32 \%)$. However, correlation was found between the two variables.

The abundance of the rough spherical phytolith type is very low in all assemblages, ranging from $0 \%$ to $3 \%$, with no difference between the assemblages taken from shrubland and grassland plots. The rough spherical type was found at values greater than $1 \%$ in five of the nine shrubland assemblages and in two of the fourteen grassland assemblages.

Abundances of the smooth spherical type range between $0 \%$ and $5 \%$ in both grassland and forest assemblages.

The spherical-with-sockets phytolith type, varies between $0 \%$ and $4 \%$ in all assemblages, and is not found at greater proportions in the samples taken from pinewoods.

\subsection{Pollen}

The pollen spectra are dominated by Pinus, Cedrus, Quercus ilex, Quercus coccifera, deciduous Quercus, Buxus sempervirens and Poaceae (Fig. 2). The four vegetation groups cannot be distinguished on the basis of their pollen spectra. $Q$. ilex and $Q$. coccifera pollen were abundant in both shrubland and grassland spectra. For example, in CPL11, a grassland plot covered by less than $1 \%$ of $Q$. ilex, pollen abundance of $Q$. ilex and $Q$. coccifera account for $39 \%$ of the total pollen sum. Pinus pollen was found at high proportions in all spectra. In order to better interpret the composition of pollen spectra in relation to the vegetation groups, we have applied the biomization method to the pollen samples. This method assigns pollen spectra to the biome with which it has the highest affinity (Prentice et al., 1996; Peyron et al., 1998). Once calculated, the chosen biomes were then compared with the vegetation groups. The majority of the spectra are assigned to the Warm Xerophytic biome, a biome commonly used for describing Mediterranean vegetation. Two plots were assigned to a Temperate Deciduous biome (CPL04 and CPL06), due to the high abundance of arboreal pollen taxa such as Pinus and Cedrus.

\section{Discussion}

The methodological questions raised in introduction can now be assessed, in the light of the main results of this study:

(1) The studied soil phytolith assemblages show for the first time that whilst the amount of soil phytoliths recovered is low, they occur in sufficient quantities to allow statistical counting, despite the low levels of $\mathrm{SiO}_{2}$ in the parent rock. This result confirms that phytolith analysis can be used as a record of the vegetation developed on carbonaceous soils, and provides support for the hypothesis of active uptake of silica by plants (Lauwers and Heinen, 1974; Kaufman et al., 1981; Raven, 1983).

(2) Pooideae phytoliths are dominant in all modern assemblages. The variations of the proportion of these types in samples taken from grassland to forest and shrubland assemblages are not sufficient enough to allow differentiation between the three vegetation types. However, the abundance of the crenate type appears more dependent on the percentage of Poaceae species occurring on a given plot. Shrubland and grassland assemblages show, respectively, low and high proportion of this type. This relation was not found between the other short cell phytolith types, and may be explained by differences in phytolith production between subfamilies. This hypothesis would suggest that grass species settled in open areas would produce the crenate type in higher quantities than grass species growing in closed areas. However, statistical analysis of the relationships between grass phytolith type and grass species abundance did not show any correlation between the variables and does not provide any support for this hypothesis. A second hypothesis is that phytolith type production varies within the same species in indirect relation to the tree and shrub cover density.

Non-Pooideae grass subfamilies that may occur in the Mediterranean area (e.g. Arundinoideae grass subfamily) were not found in any of the studied plots. As phytolith analysis is unable to discriminate further than grass subfamilies, the studied assemblages show a homogeneous grass cover. The same limitation will 
occur anywhere where the study site is located in a mono-subfamily grass cover.

(3) One aim of this study was to examine if the phytolith index of tree cover density, commonly used in tropical studies (Alexandre et al., 1997, 1999; Barboni et al., 1999), may be used for Mediterranean vegetation reconstructions. Our results show that the rough spherical type, produce by ligneous dicotyledon, occurs at very low quantities in the oak forest and shrubland assemblages. When the smooth spherical types are added to the rough spherical types in the $\mathrm{d} / \mathrm{p}$ index, as proposed by Delhon et al. (2003), the new index remains low and shows no relation to the tree cover density. This result suggests that oaks, whilst dominating the tree cover of the studied plots, do not produce the rough spherical phytolith type in sufficient quantities to be used as an indicator. This applies equally to the other dicot species observed on the plots. A review of phytolith studies from temperate and cool areas (Twiss, 1983; Tsutsuki et al., 1993; Fredlund and Tieszen, 1994, 1997) shows that this type is absent from the reported phytolith assemblages, which strengthens the hypothesis of a low production of the rough spherical phytolith type by non-tropical dicot species. Albert et al. $(1999,2000)$ found a small proportion of spheroid scabrate or verrucated phytoliths, similar to the rough spherical type, from samples taken both inside and outside of a cave in Israel (Mediterranean zone). However, the source of this phytolith type was not identified. As the studied oak groves were recently established (mainly within the last 50 years), the proportions of the rough spherical types may have been further reduced in the soil samples, as these would contain a record of phytolith deposition over a greater period of time.

Although most tropical woody dicotyledon species appear to produce the rough spherical type, this is not true of the North Mediterranean woody species. Therefore, care must be taken when using the $\mathrm{d} / \mathrm{p}$ ratio for estimating tree cover density in the North Mediterranean area. Further investigation of temperate and Mediterranean woody dicotyledon species producing this type is required to reach a better understanding of the meaning of the $\mathrm{d} / \mathrm{p}$ phytolith ratio in non-tropical areas.

(4) Our results show that the abundances of the spherical-with-sockets phytolith type cannot be used to identify the pinewood studied here, dominated by Pinus halepensis, Pinus nigra and Pinus sylvestris. A number of different pine phytolith types have been identified (Klein and Geis, 1977; Kondo et al., 1994; Kerns, 2001; Kerns et al., 2001; Blinnikov et al., 2002), some of which are morphologically similar to the spherical-with-sockets identified by Delhon et al. (2003) as a pine tracer. However, these were only observed in tissue and they may not be preserved in soil assemblages, due to selective dissolution and fragmentation in the litter. Further, as the sphericalwith-sockets type does not have a distinct morphology and may be confused with other weathered phytolith types, comparisons must be made with care.

Kerns et al. (2001) studied soil phytolith assemblages under a pine forest dominated by Pinus ponderosa. The authors found high proportion of a "spiny body" phytolith type. SEM photographs of this type show it to be similar to the "spherical-withsockets" type. However, the relation between the abundance of this type and pine cover is not clear. Further examination of modern assemblages collected under pinewoods of different age and dominant species is required before the reliability of the spherical-with-sockets phytolith type as a pine tracer can be assessed.

(5) The heterogeneity of the vegetation physiognomy of the studied plots is mainly due to changes in the height and density of tree and shrub cover height instead of the composition of tree species. Such short distance changes in plant physiognomy are not reflected in the soil phytolith assemblages. This is mainly due to the absence of characteristic phytoliths produced by oaks, which dominate the studied site and are widespread in the Mediterranean area.

In addition, modern phytolith assemblages are representative of the vegetation composition over a period of many years. Examination of the vegetation dynamics over the last 100 years shows a change from open to closed vegetation. We assumed that modern phytolith assemblages from the first centimeter of soil humic horizons represent the vegetation dynamics of a period between a few years and a few hundred years. If soil samples record more than 100 years of phytolith deposition, then the recent establishment of shrublands and pinewoods in this area may not be mirrored by phytolith assemblages. This may explain the lack of the forest signal noted above. However, three oak 
groves are older than 100 years and should be recorded by phytolith assemblages. As they are not, we assume that these forests do not produce characteristic phytolith signal.

The different vegetation groups on the massif could not be distinguished using pollen analysis. The pollen spectra studied here record a regional vegetation signal, resulting from transportation of pollen by the strong and frequent winds which are characteristic of the area.

\section{Conclusion}

This first attempt at calibrating of modern soil phytolith assemblages with pollen and botanical data at a North Mediterranean site has shown the following benefits and limitations of phytolith analysis for the reconstruction of Mediterranean vegetation.

Phytoliths are produced in sufficient quantities for analysis and are well preserved in limestone environments, widespread in the Mediterranean area. Examination of the phytolith record from soils and buried soils as well as from carbonaceous sediments may help to compensate for the current lack of continental paleoenvironmental records in this area. However, the phytolith index commonly used for tracing the tree cover density in tropical areas cannot be used in the Mediterranean domain without further confirmation of its reliability. Our study shows that young Quercus ilex, Quercus coccifera and Quercus pubescens, which are widespread both today and during the Holocene in the North Mediterranean area, do not produce characteristic phytolith types in sufficient amounts to allow a reliable index to be calculated. Variations in the pine cover, dominated by Pinus halepensis and Pinus sylvestris, are also not recorded in the studied phytolith assemblages.

The phytolith assemblages are mainly composed of grass phytoliths and this provides some useful information on the grass cover. The proportion of Pooideae grasses relative to the non-grass species appears to be shown in the grass phytolith assemblages: grassland and shrubland assemblages can be distinguished by their proportion of crenate phytoliths. This relation needs to be confirmed and explain by further studies on similar vegetation characterized by grass cover exclusively composed of Pooideae.
Finally, whilst phytolith analysis has been shown to be reliable for recording changes in the subfamilies form the grass cover in temperate, cold and intertropical areas, this technique appears to be of limited use for recording Mediterranean vegetation changes, which usually do not induce a sufficient change in grass cover. Further testing is required on modern assemblages originating from forests which have been in place for several centuries to further assess the ability of phytolith analysis to record the tree cover density in temperate and Mediterranean areas.

\section{Acknowledgements}

This study was done at CEREGE, Aix en Provence, in the framework of $\mathrm{L}$. Bremond $\mathrm{PhD}$ thesis. Pollen samples were prepared in IMEP/CNRS, Marseille. Pollen counting were done by Sabina Rossi and Yoann Tantau. We are grateful to Sophie Gachet for helpful comments and suggestions and to Simon Brewer for English revision.

This work was supported by SEAH/PIREVS (Programme Intedisciplinaire de Recherche en Environnement, Vie et Société of CNRS) and by PNEDC (Programme National d'Etudes Dynamique du Climat, INSU).

\section{References}

Albert, R.M., Tsatskin, A., Ronen, A., Lev-Yadun, S., 1999. Mode of occupation of Tabun cave, Mt. Carmel, Israel during the Mousterian period: a study of the sediments and phytoliths. J. Archaeol. Sci. 26, 1249-1260.

Albert, R.M., Weiner, S., Bar-Yosef, O., Meignen, L., 2000. Phytoliths in the middle palaeolithic deposits of Kebara Cave, Mt. Carmel, Israel: study of the plant materials used for fuel and other purposes. J. Archaeol. Sci. 27, 931-947.

Alexandre, A., Meunier, J.-D., Lézine, A.-M., Vincens, A., Schwartz, D., 1997. Phytoliths indicators of grasslands dynamics during the late Holocene in intertropical Africa. Palaeogeogr. Palaeoclimatol. Palaeoecol. 136, 213-219.

Alexandre, A., Meunier, J.-D., Mariotti, A., Soubies, F., 1999. Late Holocene phytolith and carbon-isotope record from a latosol at Salitre, South-Central Brazil. Quat. Res. 51, 187-194.

Alexandre, A., Bouvet, M., Meunier, J.-D., 2000. Phytolith and the biochemical cycle of silicon in a savanna ecosystem, 3rd I.M.P.R. Man and the (palaeo)environment. The Phytolith Evidence. Tervuren, Belgium, pp. 1-2.

Barboni, D., Bonnefille, R., Alexandre, A., Meunier, J.D., 1999. 
Phytoliths as palaeoenvironmental indicators, west side Middle Awash Walley, Ethiopia. Palaeogeogr. Palaeoclimatol. Palaeoecol. 152, 87-100.

Blinnikov, M., Busacca, A., Whitlock, C., 2002. Reconstruction of the late Pleistocene grassland of the Columbia basin, Washington, USA, based on phytolith records in loess. Palaeogeogr. Palaeoclimatol. Palaeoecol. 177, 77-101.

Blondel, J., Aronson, J., 1999. Biology and Wildlife of the Mediterranean Region. Oxford Univ. Press, New York. 327 pp.

Cheddadi, R., Yu, G., Guiot, J., Harrison, S.P., Prentice, I.C., 1997. The climate of Europe 6000 years ago. Clim. Dyn. 13, 1-9.

Cheddadi, R., Guiot, J., Jolly, D., 2001. The Mediterranean vegetation: what if the atmospheric $\mathrm{CO}_{2}$ increased? Landsc. Ecol. 16 (7), 667-675.

Combourieu-Nebout, N., Paterne, M., Turon, J.L., Siani, G., 1998. A high-resolution of the last deglaciation in the central Mediterranean sea: palaeovegetation and palaeohydological evolution. Quat. Sci. Rev. 17, 303-317.

Delhon, C., Alexandre, A., Berger, J.-F., Thiébault, S., Brochier, J.-L., Meunier, J.-D., 2003. Phytolith assemblages as a promising tool for reconstructing Mediterranean Holocene vegetation. Quat. Res. 59 (1), $48-60$.

Di Castri, F., Goodall, D.W., Spetch, R.L., 1981. Mediterraneantype shrublands. Ecosystems of the World, vol. 11. Elsevier, Amsterdam. 643 pp.

Digerfeldt, G., de Beaulieu, J.L., Guiot, J., Mouthon, J., 1997. Reconstruction and paleoclimatic interpretation of Holocene lake-level changes in Lac de Saint-Léger, Haute-Provence, southeast France. Palaeogeogr. Palaeoclimatol. Palaeoecol. 136 (1-4), 231-258.

F.A.O., 1998. World reference base for soil resources, FOOD AND AGRICULTURE ORGANIZATION OF THE UNITED NATIONS, Rome.

Fauquette, S., Suc, J.P., Guiot, J., Diniz, F., Feddi, N., Zheng, Z., Bessais, E., Drivaliari, A., 1999. Climate and biomes in the western Mediterranean area during the Pliocene. Palaeogeogr. Palaeoclimatol. Palaeoecol. 152, 15-36.

Fredlund, G.G., Tieszen, L.T., 1994. Modern phytolith assemblages from the North American Great Plains. J. Biogeogr. 21 (3), $321-335$.

Fredlund, G., Tieszen, L.T., 1997. Calibrating grass phytoliths assemblages in climatic terms: application to the late Pleistocene assemblages from Kansas and Nebraska. Palaeogeogr. Palaeoclimatol. Palaeoecol. 136, 199-211.

Godron, M., Daget, P., Emberger, L., Long, G., Le Floch, E., Poissonet, J., Sauvage, C., Wacquant, J.P., 1983. Code pour le relevé méthodique pour la végétation et du milieu. Principes et transcription sur cartes perforées CNRS, Paris. 292 pp.

Guiot, J., Torre, F., Cheddadi, R., Peyron, O., Tarasov, P., Jolly, D., 1999. The climate of the Mediterranean basin and of Eurasia of the last glacial maximum as reconstructed by inverse vegetation modelling and pollen data. Ecol. Mediterr. 2 (2), 193-204.

Heinz, C., Thiébault, S., 1998. Characterization an palaeoecological significance of archaeological charcoal assemblage during late and post-glacial phases in Southern France. Quat. Res. $50,56-68$.
Jalut, G., Amat, A.E., Bonnet, L., Gauquelin, T., Fontugne, M., 2000. Holocene climatic changes in the Western Mediterranean, from south-east France to south-east Spain. Palaeogeogr. Palaeoclimatol. Palaeoecol. 160 (3-4), 255-290.

Kaplan, L., Smith, M.B., Sneddon, L.A., 1992. Cereal grain phytoliths of Southwest Asia and Europe. In: Rapp, G.J., Mulholland, S.C. (Eds.), Phytoliths Systematics, Emerging Issues. Advances in Archaeological and Museum Science. Plenum Press, New York, pp. 149-174.

Kaufman, P.B., Dayanandan, P., Takeoka, W.C., Bigelow, W.C., Jones, J.D., Iler, R., 1981. Silica in shoots of higher plants. In: Simpson, J.L., Volcani, B.E. (Eds.), Silicon and Siliceous Structure in Biological Systems. Springer Verlag, New York, p. 587.

Kelly, E.F., 1990. Method for extracting opal phytoliths from soil and plant materialIntern. Rep.-Dep. Agron. Colorado State University, Fort Collins.

Kerns, B.K., 2001. Diagnostic phytoliths for Ponderosa pinebunchgrass community near Flagstaff, Arizona. Southwest. Nat. 46 (3), 282-294.

Kerns, B.K., Moore, M.M., Hart, S.C., 2001. Estimating forestgrassland dynamics using soil phytolith assemblages and D13C of soil organic matter. Ecoscience 8 (4), 478-488.

Klein, R.L., Geis, J.W., 1977. Biogenic silica in the Pinaceae. Soil Sci. 126 (3), 145-156.

Kondo, R., Childs, C., Atkinson, I., 1994. Opal Phytoliths of New Zealand. Manaaki Whenua Press, Lincoln, Canterbury, 85 pp.

Lauwers, A.M., Heinen, W., 1974. Bio-degradation and utilization of silica and quartz. Archaeol. Microbiol. 95, 67-78.

Mulholland, S.C., 1989. Phytoliths shape frequencies in North Dakota grasses: a comparison to general patterns. J. Archaeol. Sci. 16, 489-511.

Palmer, P.G., Gerbeth-jones, S., Hutchison, S., 1985. A scanning electron microscope survey of the epidermis of East African grasses, III. Smithsonian Contributions to Botany, vol. 55. Smithsonian Institution, Washington. $135 \mathrm{pp}$.

Peyron, O., Guiot, J., Cheddadi, R., Tarasov, P., Reille, M., Beaulieu de, J.L., Bottema, S., Andrieu, V., 1998. Climatic reconstruction in Europe for 18,000 yr B, P. from pollen data. Quat. Res. 49, 183-196.

Piperno, D.P., 1988. Phytolith Analysis-An Archaeological and Geological Perspective. Academic Press/Harcourt Brace Jovanovich, New York, US 1 volume: 280 pp.

Prentice, I.C., Guiot, J., Huntley, B., Jolly, D., Cheddadi, R., 1996. Reconstitution biomes from palaeoecological data: a general method and its application to European data at 0 and $6 \mathrm{ka}$. Clim. Dyn. 12, 185-194.

Raven, J.A., 1983. The transport and function of silicon in plants. Biol. Rev. 58, 179-207.

Reille, M., 1990. Leçon de palynologie et d'analyse pollinique, Edition du CNRS, 206 pp.

Rose, J., Meng, X., Watson, C., 1999. Palaeoclimate and paleoenvironmental response in western Mediterranean over the last 140 ka: evidence from Mallorca, Spain. J. Geol. Soc. Lond. 156, $435-448$.

Sangster, A.G., Williams, S.E., Hodson, M.J., 1997. Silica deposition in the needles of the gymnosperms: II. Scanning electron microscopy and X-ray microanalysis. In: Pinilla, A., 
Tatoni, T., Machado, M.J. (Eds.), Estado actual de los estudios de fitolitos en suelos y planta/The state-of-the-art of phytoliths in soils and plants. Monografias 4 del Centro de Ciencias Medioambientales. CSIC, Madrid, p. 292.

Scurfield, G., Anderson, C.A., Segnit, E.R., 1974. Silica in woody stems. Aust. J. Bot. 22, 211-229.

Tatoni, T., Vela, E., Dutoit, T., Roche, P., 1998. Présentation du suivi scientifique et des premiers résultats concernant l'organisation de la végétation dans le Luberon. Courrier Scientifique du Parc naturel du Luberon 2, 32-49.

Thiébault, S., 1997. Early Holocene vegetation and the human impact in central Provence (Var, Franc): charcoal analysis of the Baume de Fontbrégoua. Holocene 7 (3), 343-349.

Thinon, M., 1979. Incidence écologique des reboisements du Mont Ventoux (Vaucluse). Aspects floristiques et pédologiques, AixMarseille 3, Marseille, 117 pp.

Thinon, M., 1992. L'analyse pédoanthracologique. Aspects méthodologiques et applications, Aix-Marseille 3, Marseille, 317 pp.

Tsutsuki, K., Kondo, R., Shiraishi, H., Kuwastsuka, S., Group, O.W.R., 1993. Composition of lignin-degradation products, lipids, and opal phytoliths in a peat profile accumulated since 32,000 years B.P. in central Japan. Soil Sci. Plant. Nutr. 39 (3), $463-474$.

Twiss, P.C., 1983. Dust deposition and opal phytoliths in the great plains. Transactions of the Nebraska Academy of Sciences, vol. XI, pp. 73-82. Special issue.

Twiss, P.C., 1987. Grass-opal phytoliths as climatic indicators of the Great Plains Pleistocene. In: Johnson, W.C.E. (Ed.), Quaternary Environments of Kansas. Kansas Geological Survey, Laurence, KS, pp. 179-188. Guidebook.

Twiss, P.C., 1992. Predicted world distribution of C3 and C4 grass phytoliths. In: Rapp, G.J., Mulholland, S.C. (Eds.), Phytoliths Systematics Emerging Issues. Advances in Archaeological and Museum Science. Plenum Press, New York, pp. $113-128$.

Twiss, P.C., Suess, E., Smith, R.M., 1969. Morphological classification of grass phytoliths. Proced. Soil Sci. Soc. Am. 33, $109-115$.

Véla, E., 2002. Biodiversité des milieux ouverts en région méditerranéenne. Le cas de la végétation des pelouses sèches du Luberon (Provence calcaire). Université Aix-Marseille III, $383 \mathrm{pp}$.

Véla, E., Garde, L., Tatoni, T., 1998. Approche diachronique des changements dans la populations des plantes rares sur la crête du Grand Luberon. Courier Scientifique du Parc naturel du Luberon 2, 50-69.

Vernet, J.-L., 1997. L'homme et la forêt méditerranéenne, de la Préhistoire à nos jours. Editions errance, 248 pp. 